\title{
PRELIMINARY DATA FROM THE FIRST RECORD OF THE EARLY TOARCIAN OCEANIC ANOXIC EVENT IN THE SEDIMENTS OF THE PINDOS ZONE (GREECE)
}

\author{
Kafousia N. ${ }^{1}$, Karakitsios V. ${ }^{1}$, and Jenkyns H.C. ${ }^{2}$ \\ ${ }^{1}$ Department of Geology and Geoenvironment, National University of Athens, Panepistimiopolis, \\ 15784 Athens, Greece,nkafousia@geol.uoa.gr,vkarak@geol.uoa.gr \\ ${ }^{2}$ Department of Earth Sciences, University of Oxford, Parks Road, Oxford OX1 3PR, United Kingdom, \\ hughj@earth.ox.ac.uk
}

\begin{abstract}
The Early Toarcian Oceanic Anoxic Event (ca 183 Ma) coincides with high palaeotemperatures, regional anoxia to euxinia, marine transgression, mass extinction and high rates of organic-carbon burial in a global context. Most of the detailed studies of this event have investigated deposits formed in the epicontinental seas of northern Europe, although coeval organic-rich shales are known locally in the Tethyan region. However, the global or regional character of this event is still under debate. In this study we present, for the first time, a high-resolution geochemical record of the Early Toarcian Oceanic Anoxic event in pelagic sediments (Kastelli Pelites) formed in a long-lived Mesozoic deep-sea basin, corresponding to the western passive margin of the Pindos Ocean of western Greece.

Our data record both the positive excursion in total organic carbon (TOC) and the characteristic negative excursion in $\delta^{13} C_{\text {carb }}$. The $\delta^{13} C_{\text {carb }}$ values are very stable in the bottom of the section ( 2\%o), whereas higher in the section the values drop down to $\sim-5 \%$. Following this negative excursion, the carbonate carbon-isotope ratios return to background values. The TOC excursion is modest, rising from a background of $0.05 \%$ to $\sim 2 \%$ and then returning to a background of $0.04 \%$.

Because both relative enrichment in TOC and the negative carbon-isotope excursion that characterize the Toarcian OAE are recorded in some of the deepest marine sediments of the Tethyan region, the global significance of the event is reinforced.
\end{abstract}

Key words: Toarcian, Oceanic Anoxic Event, Pindos Zone.

\section{Introduction}

The early Toarcian (ca $183 \mathrm{Ma}$ ) coincides with high palaeotemperatures (Bailey et al. 2003), regional anoxia to euxinia, marine transgression, mass extinction (Little and Benton 1995) and high rates of organic-carbon burial, attributed to a so-called Oceanic Anoxic Event (Schlanger and Jenkyns 1976; Jenkyns 1988; Karakitsios 1995; Rigakis and Karakitsios 1998; Jenkyns et al. 2001). The geochemical characteristics of the early Toarcian OAE (or T-OAE) are a relative maximum in total organic carbon (TOC) and a broad, locally subdued positive carbon-isotope excursion punctuated by an abrupt negative excursion, recorded in marine organic matter, marine pelagic and shallow-water carbonate and terrestrial organic material (Jenkyns and Clayton, 1986, 1997; Hesselbo et 


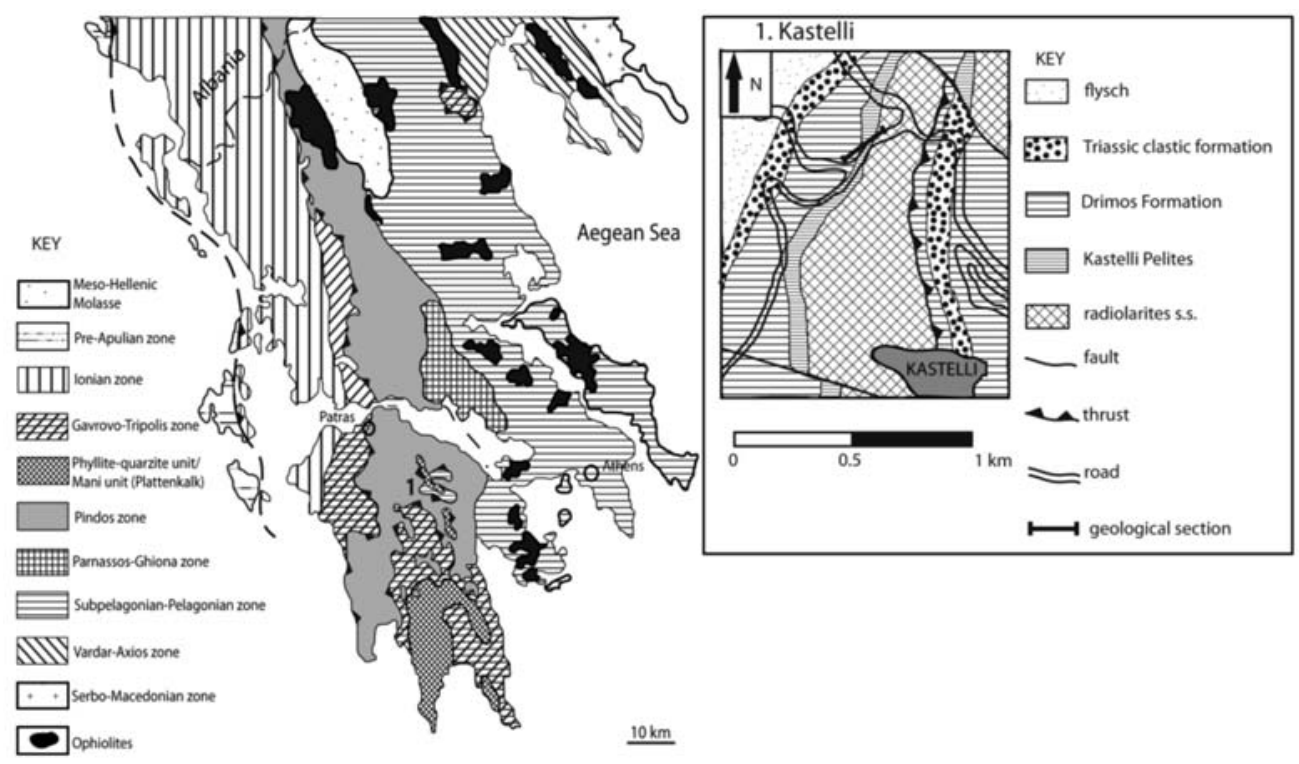

Fig. 1: (left): Simplified geological map showing the main tectono-stratigraphic zones of the Hellenides; (right): Geological map illustrating the general position of the Kastelli section.

al. 2000; Jenkyns et al. 2001; Jenkyns, 2003, 2010; Kemp et al. 2005; Hesselbo et al. 2007; Woodfine et al., 2008). Most of the detailed studies of this event have investigated deposits formed in the epicontinental seas of northern Europe (e.g. Hesselbo et al. 2000; Kemp et al. 2005), although coeval organic-rich shales are known locally in the Tethyan region (Jenkyns et al., 1985; Jenkyns and Clayton, 1986; Jenkyns, 1988; Sabatino et al. 2009). However, the global or regional character of this event is still under debate (van der Schootbrugge et al. 2005; Hesselbo et al. 2007; Suan et al. 2008).

In this study we present, for the first time, a high-resolution geochemical record of the Early Toarcian Oceanic Anoxic event in pelagic sediments formed in a long-lived Mesozoic deep-sea basin, corresponding to the western passive margin of the Pindos Ocean of western Greece. We undertook Total Organic Carbon (TOC) and stable carbon-isotopic analyses in the Kastelli section from the Pindos Zone (North Peloponnesus).

\section{Geological setting}

The study area is located to the Pindos Zone (Western Greece) which belongs to the external Hellenides (Fig. 1). The sediments of the Pindos Zone originate from an elongate remnant ocean basin that formed in mid-Triassic times along the north-east passive margin of Apulia between the extensive Gavrovo-Tripolis platform in the present west and the Pelagonian continental block in the east (Degnan and Robertson 1998). The Pindos Zone of Western Greece is exceptional because it was deformed into a regular series of thrust sheets during its emplacement, with a minimum of disruption. The present-day westward-vergent fold and thrust sheets have not been affected by major backthrusting or out-of-sequence thrusting. The sedimentary successions of the Pindos Zone comprise deep-water carbonate, siliciclastic and siliceous rocks, ranging in age from Late Triassic to Eocene (Fleury 1980). Degnan and Robertson (1998) describe the series as follows: the oldest sediments (Carnian) comprise disrupted siliciclastic turbidites (with plant remains), largely derived from a 

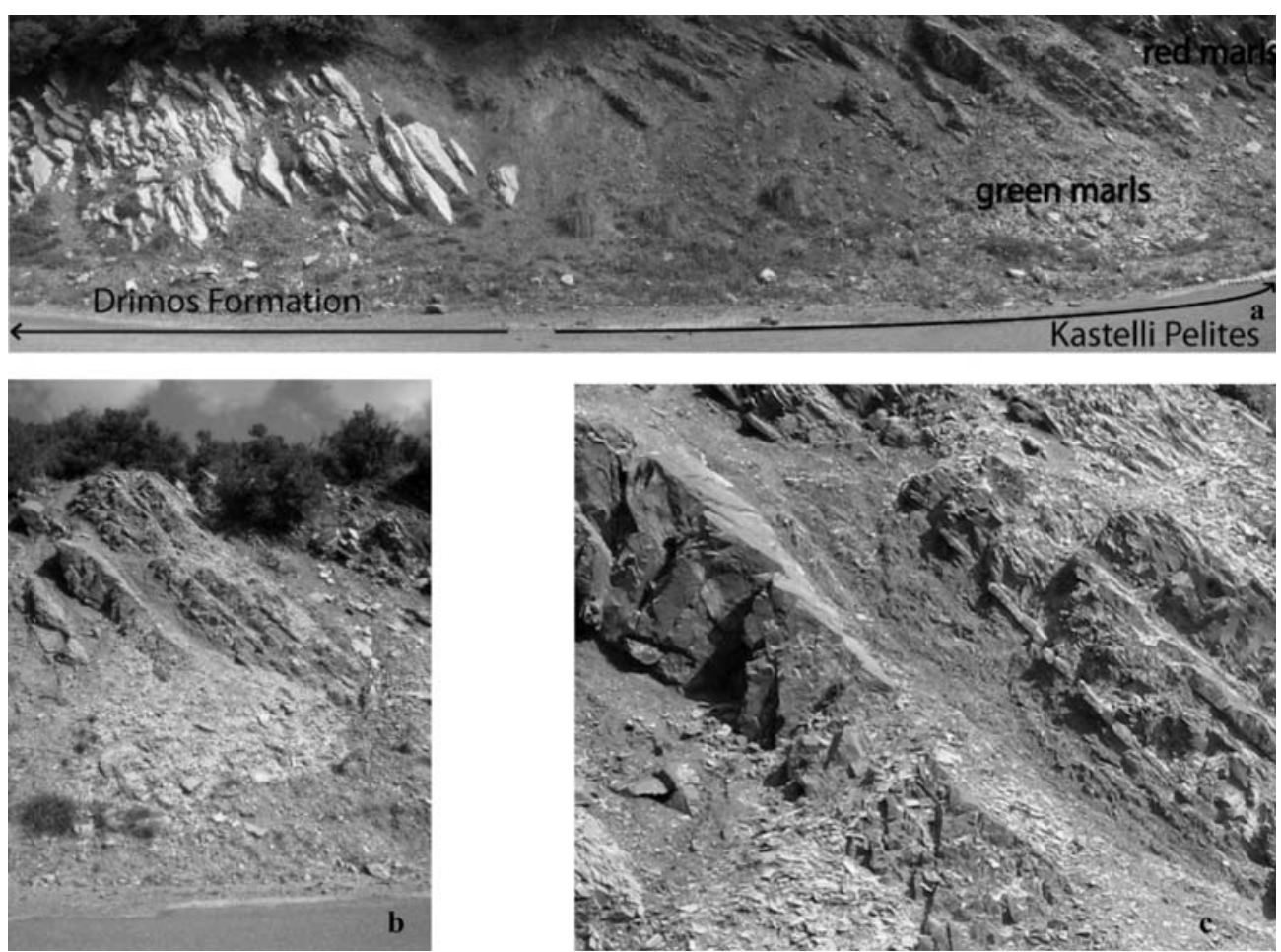

Fig. 2: (a): view of the whole section (b): green marls at the base of the Kastelli Pelites formation (c): detail of the green marls.

metamorphic source to the west and deposited on young oceanic basement. From the Norian to the end-Maastrichtian, variable thicknesses of hemipelagic-pelagic carbonates, marls and proximal carbonate debris flows accumulated in westerly areas, while mainly pelagic carbonate and more distal calciturbidites were deposited further east. This pattern was interrupted by an extended period of siliceous, radiolarian-dominated sedimentation (radiolarites) during the Aalenian to Tithonian stages of the Jurassic. From the Maastrichtian onwards, progressive closure of the Pindos oceanic basin is recorded by a gradual change in sediment composition (late Maastrichtian "couches de passage") from dominantly carbonate deposition to siliciclastic sediment (flysch) derived from the north and east. During the Eocene, complete closure of the Pindos Ocean resulted in the detachment of its deep-sea sedimentary cover from its oceanic basement as an accretionary prism and emplacement westwards onto the adjacent carbonate platform, ending up as a series of thin-skinned thrust sheets.

In the Kastelli section (Fig. 1 and 2), from bottom to top, the following are observed:

- Drimos Formation, which in the upper part comprises mainly limestones attaining some $60 \mathrm{~m}$ in thickness. The observed faunas in this upper part, containing only some reworked algae and Foraminifera (e.g. Thaumatoporella sp. and Textulariida respectively), do not allow determination of a precise age.

- Kastelli Pelites, comprising sediments of about $35 \mathrm{~m}$ thick. The first $5 \mathrm{~m}$ consists of a succession of thin-layered $(5-10 \mathrm{~cm})$ marly limestones alternating with marls, followed by a succession of $10 \mathrm{~m}$ of mainly green organic carbon-rich clays, marly limestones and rare chert intercalations. The section 
continues with about $10 \mathrm{~m}$ of red marls and some intercalations of marly limestones, followed by 5 $\mathrm{m}$ of red-green marly limestones and marls. In thin-sections of the marly limestones, badly preserved Foraminifera are observed. The succession ends with $5 \mathrm{~m}$ of marly limestones and red marls, cherty at top. These cherts indicate a passage into the stratigraphically overlying radiolarites s.s.

There are very few data concerning the age of Kastelli Pelites. Lyberis et al. (1980) attributed the formation to the Upper Pliensbachian-Toarcian, comparing the palynological associations observed in the Greek mainland with those of the Vicentinian Alps, Italy. Nevertheless, the only precise data are referred to by Fleury (1980) and de Wever and Origlia-Devos (1982), who suggested an Aalenian age for the top of the Kastelli Pelites. Fleury's (1980) data are based on the presence of Meyendorffina (Lucasella) Cayeuxi (Lucas) in a limestone layer at the top of Kastelli Pelites (in the Karpenission region, central Greece); and de Wever and Origlia-Devos's (1982) data are based on foraminiferal faunas from the Peloponessus. Based on general biostratigraphic and diagnostic chemostratigraphic signatures described in an earlier (Jenkyns 1988) and the present work, we suggest that the Kastelli Pelites are correlative with other biostratigraphically well-dated Lower Toarcian black shales in Greece (e.g. Ionian Zone) and were formed during the Oceanic Anoxic Event. This interpretation would place most or all of the Kastelli Pelites in the tenuicostatum and the overlying falciferum/levisoni/serpentinum and possibly bifrons Zones (c.f. Jenkyns et al., 2002; Hesselbo et al., 2007).

\section{Methods}

A set of 191 bulk sediments was collected from the Kastelli section. The collected samples were powdered and analysed for weight percent total organic carbon using a Strohlein Coulomat 702 analyser (details in Jenkyns, 1988) and for carbonate carbon isotopes using a VG Isogas Prism II mass spectrometer (details in Jenkyns et al., 1994). All the above analyses were undertaken in the Department of Earth Sciences in the University of Oxford.

\section{Conclusions-Results}

In the Kastelli section, the TOC percentage is very low (Figure 3). The background values of TOC fluctuate around $0.10-0.20 \mathrm{wt} \%$ and cover most parts of the section. After the lowest $7.5 \mathrm{~m}$, TOC values begin to rise gradually for $1.5 \mathrm{~m}$, until the maximum value of $1.79 \mathrm{wt} \%$ is attained. After this positive excursion, values return to background values until the end of the studied section.

In the same figure the carbon-isotope values in carbonate are reported. The bulk carbonate carbonisotope values record a small positive followed by a negative excursion in the lowest metre of the section: $\delta^{13} \mathrm{C}_{\text {carb }}$ values climb up to $3.32 \%$ and drop down to $0.64 \%$. A similar excursion, but with a larger range of values, has been reported in Peniche, Portugal and Yorkshire, northeast England (Hesselbo et al. 2007; Littler et al. 2010) at the Pliensbachian-Toarcian boundary, and this age assignment is adopted for the Kastelli section. Above the stage boundary, values are stable around $2 \%$. The background values continue up to the next $7.50 \mathrm{~m}$ of the section, where $\delta^{13} \mathrm{C}_{\text {carb }}$ begins to fall irregularly, reaching a minimum of $-5 \%$. The negative excursion persists over the next $5 \mathrm{~m}$. Following that, values begin to recover and indicate a broad positive excursion up to $3.83 \%$, as seen in many other European sections whose biostratigraphy is well constrained (Jenkyns and Clayton, 1986, 1997; Jenkyns, 2003; Sabatino et al., 2009).

Comparing the TOC and carbon-isotope curves, the polarity between them is noteworthy. Such a stratigraphical coincidence between the negative carbon-isotope excursion and TOC maximum has 


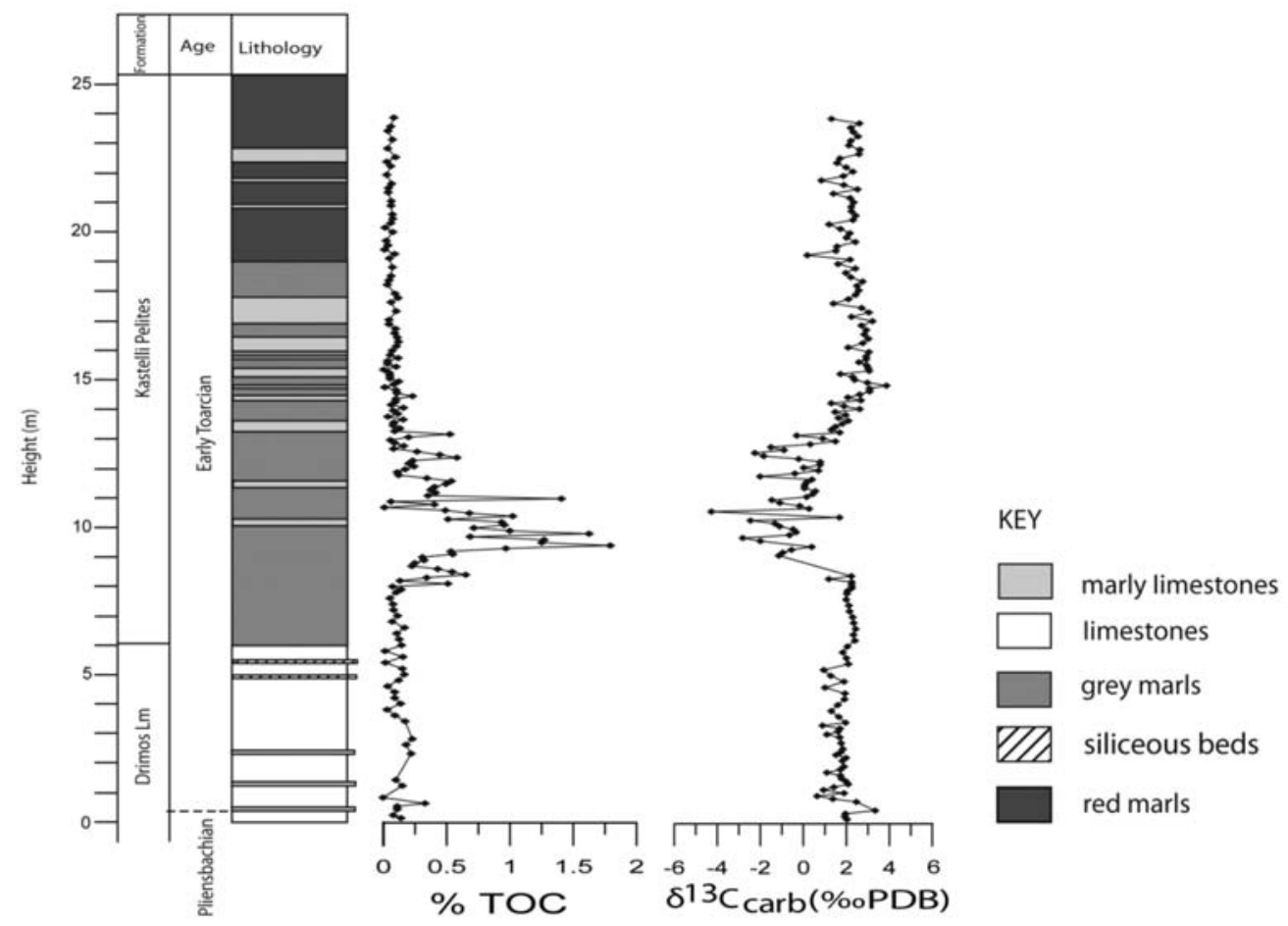

Fig. 3: Lithological column, bulk TOC and stable carbon carbonate-isotope profile for the Kastelli section.

also been observed in Lower Toarcian black shales in northern Europe (Jenkyns and Clayton 1997; Jenkyns et al. 2002). The TOC values are, however, very low compared with other coeval Toarcian sections from northern Europe, where values reach up to $15 \%$. This difference probably relates to relatively elevated organic productivity, enhanced watermass stratification, more frequent and prolonged euxinic conditions and lesser water depths in the more boreal epicontinental seaway (Jenkyns et al. 2002; Sabatino et al. 2009; Jenkyns, 2010).

Even though this research is preliminary, the record of the Toarcian OAE from these deep-marine sediments reinforces the global character of this event. Further studies of this section and comparison with coeval horizons of the Ionian Zone (lower Posidonia beds) are in progress. Integration of these results will shed further light on the causes and effects of the early Toarcian Oceanic Anoxic Event.

\section{Acknowledgements}

N.K. would like to thank the European Association of Organic Geochemistry (EAOG) for the travel scholarship she received, which gave her the opportunity to complete part of the analytical work of this research.

\section{References}

Bailey, T. R., Rosenthal, Y., McArthur, J. M. and van der Schootbrugge, B., 2003. Paleoceanographic changes of the Late Pliensbachian-Early Toarcian interval: a possible link to the genesis of an Oceanic Anoxic Event. Earth and Planetary Science Letters 212, 307-320. 
De Wever, P. and Origlia-Devos, I., 1982. Datation par les Radiolaires des niveaux siliceux du Lias de la Série du Pinde-Olonos (Formation de Drimos, Péloponnèse et Grèce continentale). C. R. Acad. Sci. Paris, sér. II 294, 1191-1198.

Degnan, P. J. and Robertson, A. H. F., 1998. Mesozoic-early Tertiary passive margin evolution of the Pindos ocean (NW Peloponnese, Greece). Sedimentary Geology 117, 33-70.

Fleury, J. J., 1980. Les zones de Gavrovo-Tripolitza et du Pinde-Olonos (Grèce continentale et Péloponèse du nord). Evolution d'une plate-forme et d'un bassin dans leur cadre alpin. Publication Societé Géol. Nord 4, 1-473.

Hesselbo, S. P., Gröcke, D. R., Jenkyns, H. C., Bjerrum, C. J., Farrimond, P., Morgans Bell, H. S. and Green, O. R., 2000. Massive dissociation of gas hydrate during a Jurassic oceanic anoxic event. $\mathrm{Na}$ ture 406, 392-395.

Hesselbo, S. P., Jenkyns, H. C., Duarte, L. V. and Oliveira, L. C. V., 2007. Carbon-isotope record of the Early Jurassic (Toarcian) Oceanic Anoxic Event from fossil wood and marine carbonate (Lusitanian Basin, Portugal). Earth and Planetary Science Letters 253(3-4), 455.

Jenkyns, H. C., 1988. The early Toarcian (Jurassic) anoxic event: stratigraphic, sedimentary, and geochemical evidence. American Journal of Science 288, 101-151.

Jenkyns, H. C., 2003. Evidence for rapid climate change in the Mesozoic-Palaeogene greenhouse world. Phil Trans. R. Soc., Series A 361, 1885-1916.

Jenkyns, H. C. 2010. The geochemistry of Oceanic Anoxic Events. Geochem. Geophys. Geosyst., doi:10.1029/2009GC002788, in press.

Jenkyns, H. C. and Clayton, C. J., 1986. Black shales and carbon isotopes in pelagic sediments from the Tethyan Lower Jurassic. Sedimentology 33, 87-106.

Jenkyns, H. C. and Clayton, C. J., 1997. Lower Jurassic epicontinental carbonates and mudstones from England and Wales: chemostratigraphic signals and the early Toarcian anoxic event. Sedimentology 44, 687-706.

Jenkyns, H.C., Sarti, M., Masetti, D. and Howarth, M.K. 1985. Ammonites and stratigraphy of Lower Jurassic black shales and pelagic limestones from the Belluno Trough, Southern Alps, Italy. Eclogae Geologicae Helvetiae, 78, 299-301.

Jenkyns, H. C., Gale, A. S. and Corfield, R. M., 1994. Carbon- and oxygen-isotope stratigraphy of the English Chalk and Italian Scaglia and its palaeoclimatic significance. Geological Magazine 131, $1-34$.

Jenkyns, H. C., Gröcke, D. R. and Hesselbo, S. P., 2001. Nitrogen isotope evidence for water mass denitrification during the Early Toarcian (Jurassic) Oceanic Anoxic Event. Paleoceanography 16, 593-603.

Jenkyns, H. C., Jones, C. E., Gröcke, D. R., Hesselbo, S. P. and Parkinson, D. N., 2002. Chemostratigraphy of the Jurassic System; applications, limitations and implications for palaeoceanography. Journal of the Geological Society of London 159, 351-378.

Karakitsios, V., 1995. The influence of preexisting structure and halokinesis on organic matter preservation and thrust system evolution in the Ionian Basin, Northwest Greece. American Association of Petroleum Geologists Bulletin 79, 960-980.

Kemp, D. B., Coe, A. L., Cohen, A. S. and Schwark, L., 2005. Astronomical pacing of methane release in the Early Jurassic period. Nature 437, 396-399.

Little, C. T. S. and Benton, M. J., 1995. Early Jurassic mass extinction: A global long-term event. Geology 23, 495-498.

Littler, K., Hesselbo, P. S. and H.C., J., 2010. A carbon-isotope perturbation at the Pliensbachian-Toar- 
cian boundary: evidence from the Lias Group, NE England. Geological Magazine, doi: 10.1017/S0016756809990458, in press.

Lyberis, N., Chotin, P. and Doubinger, J., 1980. Précisions stratigraphiques sur la série du Pinde (Grèce): la durée de sédimentation des «radiolarites». Comptes Rendus de l'Académie des Sciences, Paris, série D, 290, 1513-1516.

Rigakis, N. and Karakitsios, V., 1998. The source rock horizons of the Ionian Basin (NW Greece). Marine and Petroleum Geology 15, 593-617.

Sabatino, N., Neri, R., Bellanca, A., Jenkyns, H. C., Baudin, F., Parisi, G. and Masetti, D., 2009. Carbon-isotope records of the Early Jurassic (Toarcian) oceanic anoxic event from the Valdorbia (Umbria-Marche Apennines) and Monte Mangart (Julian Alps) sections: palaeoceanographic and stratigraphic implications. Sedimentology 56, 1307-1328.

Schlanger, S. O. and Jenkyns, H. C., 1976. Cretaceous oceanic anoxic events: causes and consequences. Geologie en Mijnbouw 55, 179-184.

Suan, G., Mattioli, E., Pittet, B., Mailliot, S. and Lecuyer, C., 2008. Evidence for major environmental perturbation prior to and during the Toarcian (Early Jurassic) oveanic anoxic event from the Lusitanian Basin, Portugal. Paleoceanography 23, PA1202, doi: 10.1029/2007PA001459.

van der Schootbrugge, B., McArthur, J. M., Bailey, T. R., Rosenthal, Y., Wright, J. D. and Miller, G. K., 2005. Toarcian oceanic anoxic event: An assessment of global causes using belemnite C isotope records. Paleoceanography 20, PA3008, doi: 10.1029/2004PA001102.

Woodfine, R.G., Jenkyns, H.C., Sarti, M., Baroncini, F. and Violante, C. 2008. The response of two Tethyan carbonate platforms to the early Toarcian (Jurassic) oceanic anoxic event: environmental change and differential subsidence. Sedimentology, 55, 1011-1028. 